Marek Szczepaniak

(Archiwum Państwowe w Poznaniu Oddział w Gnieźnie)

mszczepaniak@poznan.ap.gov.pl

Grażyna Tyrchan

(Archiwum Państwowe w Poznaniu Oddział w Gnieźnie)

gtyrchan@poznan.ap.gov.pl

\title{
Kulminacja ogólnopolskich świeckich obchodów Tysiąclecia Państwa Polskiego w Gnieźnie w kwietniu 1966 r.
}

Obchody Tysiąclecia Państwa Polskiego i Millennium Chrztu Polski odbywały się w warunkach ostrej konfrontacji między komunistyczną władzą państwową a Kościołem katolickim. Wyznaczając czas i zakres obchodów państwowych, kierowano się myślą, by stanowiły one przeciwwagę dla ceremonii kościelnych.

Wielka Sobota 9 kwietnia 1966 r. była pierwszym dniem zaplanowanych przez prymasa Stefana Wyszyńskiego gnieźnieńskich obchodów milenijnych. By zniechęcić, zwłaszcza młodzież, do udziału w nich Estrada Poznańska przygotowała na godz. 14.00 popularną imprezę z cyklu Grająca szafa, w mieszczącej 2000 miejsc wojskowej hali sportowej przy ul. Cymsa². W okresie obchodów kościelnych od 9 do 15 kwietnia zadbano o szczególnie atrakcyjny repertuar gnieźnieńskich kin: w kinie Polonia (przy ul. Chrobrego) - prapremiera Faraona, w kinie Lech (przy ul. Warszawskiej) - amerykańskie produk-

\footnotetext{
${ }^{1}$ Niniejszy artykuł jest drugą częścią referatu przygotowanego i przedstawionego podczas ogólnopolskiej sesji naukowej 1050-lecie chrztu Polski w wymiarze ogólnopolskim i regionalnym w Tomaszowie Mazowieckim . Jego pierwsza część została opublikowana w przygotowanym przez Archiwum Państwowe w Piotrkowie Trybunalskim Oddział w Tomaszowie Mazowieckim wydawnictwie pokonferencyjnym: Szczepaniak Marek, Tyrchan Grażyna: Świeckie Polskie Tysiąclecie. Przygotowanie i przebieg gnieźnieńskich obchodów jubileuszu powstania państwa polskiego w latach 1957-1966, [w:] 1050-lecie chrztu Polski w wymiarze ogólnopolskim i regionalnym, red. A. Wróbel, A. Piasta, Piotrków Trybunalski-Tomaszów Mazowiecki 2016, s. 223-246.

${ }^{2}$ Archiwum Państwowe w Poznaniu , Komitet Wojewódzki Polskiej Zjednoczonej Partii Robotniczej w Poznaniu (dalej: APP, KW PZPR w Poznaniu), sygn. 1314, s. 101, 192.
} 
cje Niagara i Złoto Alaski oraz francusko-włoska Człowiek z Rio. W plenerze odbywały się projekcje Krzyżaków i Ostatniego etapu ${ }^{3}$. Zarówno w obu kinach, jak i w plenerze, seanse rozpoczynały się o godz. 14.00 i 18.00. W pierwszy dzień świąt wielkanocnych pokazy odbyły się tylko raz - o godz. 10.00, w poniedziałek wielkanocny zaś - o godz. 10.00 i 16.00. 12-15 kwietnia projekcje miały miejsce $\mathrm{w}$ godzinach popołudniowych i wieczornych ${ }^{4}$. W imprezach kulturalnych i sportowych zorganizowanych w Gnieźnie 9-13 kwietnia frekwencja wyniosła według organizatorów 43081 osób ${ }^{5}$. Wyświetlony na rynku film pt. Krzyżacy, zgromadził ok. 5500 widzów ${ }^{6}$. Również w tych dniach prezentował gnieźnianom swój program międzynarodowy cyrk „Gryf”.

10 kwietnia przybyła do Gniezna od strony Trzemeszna wędrująca kopia obrazu Matki Boskiej Częstochowskiej. Do katedry samochód przejeżdżał ulicami Roosevelta, Dąbrówki, Pl. Bohaterów Stalingradu i Tumską. W odpowiedzi strona świecka przygotowała na trasie przejazdu obrazu imprezy przewidziane w przygotowanym przez KW PZPR Planie ważniejszych przedsięwzięć polityczno-organizacyjnych w zwiazku z obchodami Tysiaclecia Państwa Polskiego w Wielkopolsce ${ }^{7}$. W ich trakcie ludność spotykała się z oficerami i kombatantami. W tym samym dniu w Gnieźnie, w mieszczącej 500 osób sali Garbarni oraz $\mathrm{w}$ podobnej wielkości sali teatru, a także w wojskowej hali sportowej, odbywały się występy zespołów artystycznych Estrady Poznańskiej8.

Znacznie bogatszą ofertę imprez kulturalnych zaplanowano na wielkanocny poniedziałek 11 kwietnia. Już o godz. $10.00 \mathrm{w}$ hali przy ul. Cymsa odbył się trójmecz zespołów jazzowych z Gniezna, Poznania i Kalisza9. Godzinę później na Pl. Bohaterów Stalingradu odbyła się uroczysta promocja elewów szkoły artyleryjskiej w Gnieźnie na pierwszy stopień podoficerski ${ }^{10}$. O godz. 15.00 na stadionie przy ul. Wrzesińskiej przeprowadzono zawody żużlowe Startu Gniezno i Unii Leszno. W tym samym czasie na stadionie w Parku Piastowskim odbył się mecz piłki nożnej Stelli Gniezno z Lechem Poznań ${ }^{11}$.

3 Tamże, s. 186.

4 Tamże, s. 191-192.

${ }^{5}$ APP, KW PZPR w Poznaniu, sygn. 1881, s. 148. Informacja o przygotowaniach i przebiegu uroczystości Tysiąclecia Państwa Polskiego na terenie powiatu i miasta Gniezna, z dn. 16 kwietnia $1966 \mathrm{r}$.

${ }^{6}$ APP, KW PZPR w Poznaniu, sygn. 1313, s. 36. Meldunek nr 6 z dn. 15 kwietnia 1966 r., godz. 22. Przebieg uroczystych sesji powiatowych rad narodowych w województwie poznańskim.

7 APP, KW PZPR w Poznaniu, sygn. 1314, s. 91, 101.

8 Tamże, s. 192.

9 Tamże, s. 192.

10 Tamże, s. 191.

11 Tamże, s. 186, 193. Choć w sprawozdaniach Komitet Powiatowy Polskiej Zjednoczonej Partii Robotniczej w Gnieźnie (dalej: KP PZPR w Gnieźnie) obydwie imprezy sportowe przedstawiał jako zorganizowane $\mathrm{z}$ okazji Tysiąclecia, to w rzeczywistości wynikały one $\mathrm{z}$ termina- 
Po południu o godz. $16.00 \mathrm{w}$ sali teatru rozpoczęła się rewia mody zorganizowana przez gnieźnieński Zarząd PSS Społem. Do udziału w pokazie zaangażowano siedmioosobowy zespół aktorski, czteroosobowy zespół baletowy oraz grupę modelek z Warszawy. Reżyserem spektaklu był Jerzy Hoffman, autorem choreografii zaś Conrad Drzewiecki. Pokaz zaplanowano na ok. 60 minut, w czterech 4 po 15 minut. Przerywane miały być one występami artystycznymi po ok. 20 minut każdy. W pierwszej części pokazu reklamowane być miały płaszcze i kostiumy wieczorowe, w drugiej - garsonki i suknie popołudniowe, w kolejnej - suknie bawełniane, kretonowe i plażowe, w ostatniej zaś - suknie na "zielony karnawał”. Zapewniono specjalną oprawę plastyczną sceny i sali teatru oraz reklamę uliczną na trawnikach i przed sklepami odzieżowymi. Prawdziwym hitem imprezy miał być zorganizowany w holu teatru kiermasz, na którym można było kupić prezentowaną na pokazie odzież ${ }^{12}$. O godz. $17.00 \mathrm{w}$ hali przy ul. Cymsa odbył się recital zespołów występujących $\mathrm{w}$ tym czasie $\mathrm{w}$ popularnej audycji młodzieżowej poznańskiego ośrodka radia i telewizji Grająca szafa. Występy organizowane były przez Estradę Poznańską ${ }^{13}$.

We wtorek 12 kwietnia, w dniu kościelnych obchodów Dnia Młodzieży o godz. 16.00 i godz. 19.00 planowano zorganizować podobną jak 9 kwietnia imprezę muzyczną Grająca szafa. Czas jej trwania wybrano nieprzypadkowo, ponieważ o godz. 16.30 rozpoczynała się konferencja stanowa Młodzież wierna Kościołowi, a o godz. 18.00 modlitwy w intencji młodzieży polskiej ${ }^{14}$. Tego samego popołudnia odbyła się impreza pt. Wielki mecz zespołów big-beatowych z udziałem poznańskich grup Pechowcy, Radary i Szafiry (z nieznaną jeszcze wówczas wokalistką Anną Marią Szmeterling, występująca później pod pseudonimem Anna Jantar) oraz gnieźnieńskiej formacji Słowianie ${ }^{15}$.

rza rozgrywek. Mecz trzynastej kolejki spotkań o mistrzostwo wielkopolskiej klasy A w piłce nożnej między Stellą a rezerwami Lecha zakończył się porażką gospodarzy 1:3 (pierwsza drużyna Lecha walczyła wówczas o utrzymanie się w II lidze). Mecz żużlowy drugiej rundy II ligi żużlowej między Startem Gniezno a Unią Leszno również przegrali gospodarze wynikiem 36,5 : 41,5 - „Głos Wielkopolski” nr 86 (6893) z 13 kwietnia 1966 r., s. 6; www.rlach.republika.pl/ pl_1966.htm, (dostęp 28 lutego 2017).

12 APP, KW PZPR w Poznaniu, sygn. 1314, s. 193, 215-216.

13 Tamże, s. 192.

14 Tamże, s. 102.

15 „Głos Wielkopolski” nr 86 (6893) z 13 kwietnia 1966 r., s. 2. Dwa równorzędne pierwsze miejsca jury i publiczność przyznała Słowianom i Pechowcom (drugiego miejsca nie przyznano), trzecie miejsce zajęły Radary. Słowianie jako dodatkową nagrodę otrzymali dwutygodniowe wczasy w Rudnie oraz nagrane przez Polskie Radio płyty z ich utworami. Zespół grał w składzie: Marian Tomczak, Andrzej Bluge i Emilian Dymel - gitary, Franciszek Longin - perkusja i Edmund Kaczmarek - organy elektronowe. 
Dzień 13 kwietnia w kościelnym scenariuszu obchodów poświęcony był m.in. dzieciom. $Z$ tego powodu głównym organizatorem imprez świeckich na terenie Gniezna i powiatu było miejscowe harcerstwo ${ }^{16}$.

W tym samym dniu we wszystkich 181 wsiach powiatu gnieźnieńskiego odbyły się zebrania wiejskie, z udziałem oficerów wojska polskiego i aktywu FJN. W zebraniach wzięło udział łącznie 6656 osób ${ }^{17}$. W trakcie spotkań mieszkańcy kompletowali karty z zapisanymi czynami społecznymi wykonanymi w ostatnim roku obchodów Tysiąclecia. Deklarowali równocześnie, co jeszcze zostanie zrobione w każdej wsi. Zadaniem zwołującego zebranie aktywu było, oprócz dopilnowania frekwencji, tak ukierunkować działania, by dotyczyły one budowy dróg, rozbudowy szkół i pełnego zabezpieczenia wprowadzanej wówczas ośmioletniej szkoły podstawowej. Prowadzącym zebrania sugerowano, by nowe projekty zgłaszali rolnicy cieszący się zaufaniem całej wsi. Zobowiązania o podjętych czynach społecznych miały być podpisane przez uczestników zebrania wiejskiego. Wartość podjętych wówczas zobowiązań wyniosła 15667400 zł, a ostatecznie zamknęła się w kwocie $18153000 z^{118}$. W dniu następnym „karty czynów społecznych” miały być przekazane na szczebel gromadzki, a 15 kwietnia - na szczebel powiatowy. Meldunki ze wszystkich powiatów Wielkopolski dostarczone być miały do Gniezna przed wiecem, w sobotę 16 kwietnia.

W czwartek 14 kwietnia miała miejsce kulminacja kościelnych obchodów Millennium Chrztu Polski. Początkowo władze partyjne nie przewidywały w tym dniu zorganizowania szczególnej imprezy. Zamierzano jedynie, jak to określono, „środkami działania politycznego", ograniczać frekwencję na imprezach kościelnych. Planowano osiągnąć to m.in. poprzez odmowę udzielania zezwoleń na organizowanie procesji na zewnątrz budynków kościelnych $^{19}$.

Tego dnia we wszystkich gromadach powiatu gnieźnieńskiego odbyły się uroczyste sesje GRN. W trzech miastach - Czerniejewie, Kłecku i Witkowie, miały miejsce wspólne, połączone sesje gromadzkich i miejskich rad narodowych. Porządek obrad wszędzie był taki sam. Po przywitaniu radnych oraz zaproszonych gości (reprezentujących ludność gromady i największe miejscowe zakłady pracy), przewodniczący rad odczytywali specjalnie przygotowane na tę okazję referaty. Ze względu na różny poziom wystąpień stycz-

16 APP, KW PZPR w Poznaniu, sygn. 1314, s. 102.

17 APP, KW PZPR w Poznaniu, sygn. 1313, s. 39. Zestawienie ilości uczestników imprez politycznych na terenie województwa i miasta Poznania w dn. 13-17 kwietnia 1966 r.

18 APP, KW PZPR w Poznaniu, sygn. 1314, s. 213; tamże, sygn. 1881, s. 149. Informacja o przygotowaniach i przebiegu uroczystości Tysiąclecia Państwa Polskiego na terenie powiatu i miasta Gniezna, z dn. 16 kwietnia 1966 r.; APP, Prezydium Wojewódzkiej Rady Narodowej w Poznaniu (dalej: PWRN w Poznaniu), sygn. 2047, s. 127-130.

19 APP, PWRN w Poznaniu, sygn. 2047, s. 100. 
niowych, władze wojewódzkie, za pośrednictwem władz powiatowych, przygotowały zestaw dyrektyw zawierających szczegółowe wskazania problemów, jakie w referatach powinny być poruszone. $Z$ tego powodu prawie wszystkie przemówienia były bardzo do siebie podobne. W tezach do referatu nakazywano wspomnieć, że tysiącletnia historia Polski zaczynała się na ziemiach położonych nad Wartą, Odrą, Wisłą i Bałtykiem. Szeroko omawiano zmagania militarne polsko - niemieckie, bunty chłopskie oraz narodziny i rozwój polskiego ruchu robotniczego. W tezach nakazywano także, by wymienić największe osiągnięcia, jakie odnotowano na terenie gromady po II wojnie światowej. Przypominano o znaczeniu sojuszu polsko - sowieckiego i o tym, że to on gwarantuje pozostawanie ziem odzyskanych w granicach państwa polskiego. W tym kontekście krytykowano orędzie biskupów polskich do biskupów niemieckich, a rządowi zachodnioniemieckiemu wytykano dążenie do rewanżu i zagrożenia światowego pokoju. Podkreślano wagę obchodów Tysiąclecia Państwa Polskiego. Wskazywano, że Wielkopolanie nie tylko biorą udział w świątecznych obchodach, ale również podejmują czyny społeczne.

W dalszej części sesji przyjmowano meldunki mieszkańców wsi o przyjętych zobowiązaniach. W należących do gromady Czerniejewo miejscowościach Graby, Pakszyn i Rakowo zamierzano oczyścić rowy i naprawić przepusty wodne. We wsiach Goranin, Golimowo, Pakszyn, Nidom, Pawłowo, Czeluścin i Szczytniki Czerniejewskie zadeklarowano naprawę dróg. We wsi Kąpiel zamierzano posadzić 120 drzew, w Nidomiu i Szczytnikach Czerniejewskich rozbudować szkoły, we wsi Lipki pogłębić zbiornik wodny dla celów przeciwpożarowych, a pracownicy Nadleśnictwa Czerniejewo zobowiązali się zalesić około 2 ha nieużytków. W gromadzie Kiszkowo zamierzano dokonać naprawy dróg w Łubowicach i Łubowiczkach oraz połączeń Turostowo-Turostówko, Charzewo-Sroczyn, Sroczyn-Berkowo, Sroczyn-Gniewkowo. W samym Kiszkowie planowano położyć nawierzchnię na ul. Ogrodowej i sieć kanalizacyjną na ul. Szkolnej. We wsi Dąbrówka Kościelna miała powstać hydrofornia. Gromada Kłecko meldowała ogólnikowo, że prowadzone czyny społeczne skoncentrowane będą wokół remontów dróg, prac melioracyjnych, budowy wodociągów wiejskich i studni. Zamierzano także prowadzić zadrzewianie gromady ${ }^{20}$. Ostatecznie wybudowano odcinek nowej drogi z Pruchnowa do Bielaw. Sesja w Kłecku miała charakter szczegól-

${ }^{20}$ Archiwum Państwowe w Poznaniu Oddział w Gnieźnie, Prezydium Gromadzkiej Rady Narodowej (dalej: APP OG, PGRN) w Czerniejewie, sygn. 14, s. 70-102. Protokół nr 11/66 z uroczystej wspólnej sesji Gromadzkiej i Miejskiej Rad Narodowych w Czerniejewie; tamże, PGRN w Kiszkowie, sygn. 69, s. 37-48. Protokół nr 10/4/66 z sesji GRN w Kiszkowie; tamże, PGRN w Kłecku, sygn. 12, s. 122-131. Protokół nr 10/66 z wspólnej sesji Miejskiej i Gromadzkiej Rad Narodowych w Kłecku. Dokumentacja czynów społecznych dla niektórych gromad jest w aktach Prezydiów Gromadzkich Rad Narodowych niekompletna. 
nie uroczysty. Połączona ona była z pochodem około 2 tysięcy mieszkańców gromady do miejsc straceń obrońców miasta z 1939 r., złożeniem hołdu bohaterom walk i pobraniem prochów z miejsc straceń do wmurowania w postument gnieźnieńskiego pomnika Mieszka I i Bolesława Chrobrego ${ }^{21}$. W gromadzie Łubowo mieszkańcy zobowiązali się do naprawienia dróg gruntowych we wsiach Baranowo, Leśniewo, Łubowo, Myślęcin, Pierzyska, Przyborowo, Rzegnowo, Strychowo i Żydówko. Zamierzano ponadto wybudować świetlice wiejskie w Fałkowie i Pierzyskach, uruchomić punkty czerpania wody w Łubowie, Wierzycach i Woźnikach oraz przeprowadzić remont remizy strażackiej w Owieczkach i dokończyć budowę domu nauczyciela w Woźnikach. W gromadzie Mieleszyn mieszkańcy zdecydowali o budowie drogi Mieleszyn - Dobiejewo, adaptacji istniejącego budynku na salę i kawiarnię w Karniszewie, zadrzewieniu drogi lokalnej w Sokolnikach na długości 2 km i położeniu chodnika dla pieszych w Mieleszynie. W gromadzie Niechanowo wybudowano nową drogę o twardej nawierzchni z Karsewa do Mierzewa i z Żelazkowa do Goczałkowa. W samym Niechanowie ułożono wodociąg. Drogi we wsiach Anastazewo, Ostrowo, Polanowo, Powidz, Przybrodzin, Ruchocinek, Smolniki, Wiekowo i Wylatkowo zostały naprawione w czynie społecznym przez mieszkańców gromady Powidz. Przeprowadzili oni ponadto remont świetlic wiejskich w Anastazewie i Wiekowie, wybudowali $2 \mathrm{~km}$ drogi o nawierzchni twardej w Ruchocinku oraz uporządkowali po remoncie obejście szkoły w Wylatkowie. W gromadzie Skiereszewo mieszkańcy podjęli się budowy bitego traktu ze Zdziechowy do Modliszewa, drogi prowadzącej przez Goślinowo, naprawy dróg lokalnych, wybudowania pawilonu spożywczo-przemysłowego w Modliszewku, przygotowania szkoły ośmiolatki w Zdziechowie, kompleksowego zadrzewienia wsi Mnichowo oraz budowy świetlicy w Strzyżewie Paczkowym. W gromadzie Sokołowo wybudowano $1 \mathrm{~km}$ nowej drogi z Sokołowa do Gaju, naprawiono prawie $7 \mathrm{~km}$ dróg gruntowych, oczyszczono $950 \mathrm{~m}$ rowów melioracyjnych, naprawiono 4 przepusty wodne. Dla miejscowej OSP wybudowano wieżę do suszenia węży i zbiornik do wody. Zalesiono także 5 ha nieużytków na terenie Nadleśnictwa Skorzęcin. W gromadzie Witkowo zamierzano wybudować szkołę w Gorzykowie oraz wyremontować ul. Targową w Witkowie. Mieszkańcy gromady Żydowo zadecydowali o budowie chodnika dla pieszych w Żydowie oraz świetlicy wiejskiej w Gębarzewie.

Po przyjęciu odpowiedniej uchwały wybierano uczestników sztafety motocyklowej, którzy za dwa dni, bezpośrednio przed rozpoczęciem gnieźnieńskiego wiecu, będą przekazywali meldunki o wykonanych czynach

21 APP, KW PZPR w Poznaniu, sygn. 1881, s. 149. Informacja o przygotowaniach i przebiegu uroczystości Tysiąclecia Państwa Polskiego na terenie powiatu i miasta Gniezna, z dn. 16 kwietnia 1966 r. 
Komendantowi Wojewódzkiemu oraz delegatów reprezentujących gromadę podczas sobotnich uroczystości. W dziesięciu gromadach powiatu gnieźnieńskiego na planowany na dzień 16 kwietnia wiec w Gnieźnie wybrano łącznie 1249 osób, w tym zaledwie 51 kobiet (4\% wszystkich delegatów). Liczba reprezentantów poszczególnych gromad była bardzo różna i nie zależała od wielkości i liczby ludności gromady. Najwięcej osób - 234 reprezentowało gromadę Mieleszyn, 203 osoby miały pojechać ze Skiereszewa, 173 delegatów reprezentować miało gromadę Żydowo, niewiele mniej, bo 170 - gromadę Jankowo Dolne. Z gromady Powidz wybrano 154 delegatów, z Kłecka 127, a 100 - z Niechanowa. Stosunkowo niewielką gromadę Sokołowo miało reprezentować 77 osób, natomiast gromadę i miasto Witkowo - zaledwie 8 . Najmniej liczna delegacja wyjechać miała do Gniezna z Łubowa. Składała się ona zaledwie z 3 osób - sekretarza Komitetu Gromadzkiego PZPR, prezesa Gromadzkiego Komitetu ZSL i przewodniczącego Gromadzkiego Komitetu FJN. W gromadach, w których podano przynależność partyjną delegatów, członkowie PZPR stanowili łącznie 42,23\%, ZSL - 12,26\%, a bezpartyjni 45,5\% wszystkich wyjeżdżających. W niektórych gromadach reprezentantów podzielono na dwie grupy. Pierwsza z nich, skupiająca członków PZPR i ZSL, na ogół wyjeżdżała wcześniej, druga grupa, w skład której wchodziły osoby bezpartyjne, ruszała później. Każda ekipa miała osobę odpowiedzialną za wyjazd i wyznaczone miejsce zbiórki. Dwu-, trzy-godzinne sesje poszczególnych gromad, podobnie jak w styczniu, kończyła część artystyczna przygotowana przez uczniów miejscowych szkół ${ }^{22}$.

22 APP,PWRNw Poznaniu, sygn. 2047, s. 118-123.SprawozdaniePrezydium PRN w Gnieźnie ze stanu realizacji czynów podjętych z okazji obchodów 1000-lecia Państwa Polskiego na dzień 27 XI 1966 r.; APPOG, Prezydium Powiatowej Rady Narodowej w Gnieźnie (dalej: PPRN w Gnieźnie), sygn. 166, s. 8-9. Protokół nr 95/66 z posiedzenia Prezydium PRN w Gnieźnie odbytego w dn. 17 listopada 1966 r.; s. 30-33. Sprawozdanie Powiatowej Komisji Planowania Gospodarczego w Gnieźnie z realizacji czynów społecznych podjętych na zebraniach wiejskich przez ludność powiatu gnieźnieńskiego z okazji 1000-lecia Państwa Polskiego. Poprawione dane znalazły się w Sprawozdaniu Prezydium PRN w Gnieźnie ze stanu realizacji czynów podjętych z okazji obchodów 1000-lecia Państwa Polskiego na dzień 31 października 1966 r., będącego załącznikiem do Protokołu 96/66 z posiedzenia Prezydium PRN w Gnieźnie odbytego w dn. 24 listopada 1966 r.; tamże, PPRN w Gnieźnie, sygn. 166, s. 54-60; tamże, PGRN w Czerniejewie, sygn. 14, s. 70-102. Protokół nr 11/66 z uroczystej wspólnej sesji Gromadzkiej i Miejskiej Rad Narodowych w Czerniejewie; tamże, PGRN w Jankowie Dolnym, sygn. 6, s. 198-214. Protokół nr 11/66 z sesji GRN w Jankowie Dolnym; tamże, PGRN w Kiszkowie, sygn. 69, s. 37-48. Protokół nr 10/4/66 z sesji GRN w Kiszkowie; tamże, PGRN w Kłecku, sygn. 12, s. 122-131. Protokół nr 10/66 z wspólnej sesji Miejskiej i Gromadzkiej Rad Narodowych w Kłecku; tamże, PGRN w Łubowie, sygn. 6, s. 186-201. Protokół nr 9/66 z sesji GRN w Łubowie; tamże, PGRN w Mieleszynie, sygn. 10, s. 32-48. Protokół nr 9/66 z sesji GRN w Mieleszynie; tamże, PGRN w Niechanowie, sygn. 18, s. 67-79. Protokół nr 12/66 z sesji GRN w Niechanowie; tamże, PGRN w Powidzu, sygn. 22, s. 185-198. Protokół nr 10/66 z sesji GRN w Powidzu; tamże, PGRN w Skiereszewie, sygn. 12, s. 157-179. Protokół nr 9/66 z sesji GRN w Skiereszewie; tam- 
Do realizacji podjętych zobowiązań przystąpiono niezwłocznie po zakończeniu obchodów Tysiąclecia. Do lipca 1966 r. Powiatowy Zarząd Dróg Lokalnych w Gnieźnie wybudował w czynie społecznym 5,5 km dróg oraz odremontował i odnowił nawierzchnię istniejących. Łączną wartość wykonanych wówczas prac oszacowano na $5500000 \mathrm{zł}^{23}$. W gromadach Powidz, Sokołowo i Kłecko do grudnia 1966 r. wybudowano w ramach czynów $1,5 \mathrm{~km}$ więcej dróg o utwardzonej nawierzchni niż przewidywały to przyjęte w kwietniu zobowiązania. Ich ilość była tak duża, że nie dało się wszystkich ukończyć w zaplanowanym terminie. Realizację niektórych przedłużono do 1970 r. Z powodu braku dokumentacji nie rozpoczęto budowy wodociągów w Łagiewnikach Kościelnych i Kamieńcu, nie pozyskano też działki pod budowę planowanej świetlicy w Fałkowie. Inne zobowiązania przyjęto zbyt pochopnie. $Z$ tego powodu nie rozpoczęto budowy wodociągu w Niechanowie i hydroforni w Dąbrówce Kościelnej. Wydział Organizacyjno-Prawny Prezydium WRN w Poznaniu zarzucał miejskim i gromadzkim radom narodowym, że na swoich sesjach nie analizowały stopnia realizacji zobowiązań podjętych przez ludność. Pomoc udzieloną przez odpowiednie jednostki organizacyjne zapewniło jedynie Prezydium PRN, nakazując im dostarczenie fachowego nadzoru, sprzętu technicznego i materiałów budowlanych ${ }^{24}$.

Dnia 14 kwietnia miejscowa młodzież szkolna brała udział w przedstawieniu w Państwowym Teatrze im. A. Fredry w Gnieźnie. By odciągnąć rodziców od udziału w obchodach kościelnych, 14 i 15 kwietnia we wszystkich szkołach podstawowych w Gnieźnie i powiecie gnieźnieńskim zorganizowano wywiadówki, na których informowano rodziców o wynikach nauczania i wychowania za III okres roku szkolnego 1965/66 25 .

$\mathrm{W}$ godzinach przedpołudniowych zorganizowano kiermasz atrakcyjnych artykułów przemysłowych i książek ${ }^{26}$. Po południu dwustuosobowy Centralny Zespół Artystyczny Wojska Polskiego w sali gnieźnieńskiego teatru dał dwa przedstawienia, które łącznie obejrzało około 3000 widzów ${ }^{27}$.

że, PGRN w Sokołowie, sygn. 22, s. 34-46. Protokół nr 11/66 z sesji GRN w Sokołowie; tamże, PGRN w Witkowie, sygn. 19, s. 60-81. Protokół nr 9/66 z sesji GRN w Witkowie; tamże, PGRN w Żydowie, sygn. 8, s. 150-176. Protokół nr 10/66 z sesji GRN w Żydowie

${ }^{23}$ APPOG, Prezydium Miejskiej Rady Narodowej w Gnieźnie (dalej: PMRN w Gnieźnie), sygn. 31, s. 9. Protokół nr XIV/VII/66 z przebiegu uroczystej wspólnej sesji PMRN w Gnieźnie oraz Miejskiej i Gromadzkiej Rady Narodowej w Witkowie odbytej w dn. 20 lipca 1966 r.

${ }^{24}$ APP, PWRN w Poznaniu, sygn. 2047, s. 127-130.

25 APP, KW PZPR w Poznaniu, sygn. 1314, s. 201, 213.

26 APP, KWPZPR w Poznaniu, sygn. 1881, s. 148. Informacja o przygotowaniach i przebiegu uroczystości Tysiąclecia Państwa Polskiego na terenie powiatu i miasta Gniezna, z dn. 16 kwietnia $1966 \mathrm{r}$.

27 APP, KW PZPR w Poznaniu, sygn. 1313, s. 36. Meldunek nr 6 z dn. 15 kwietnia 1966r., godz. 22. Przebieg uroczystych sesji powiatowych rad narodowych w województwie poznańskim; tamże, sygn. 1314,s. 192. Plan działalności KP PZPR w Gnieźnie w okresie od 16 III 1966 
O godz. 16.00 i 19.00 rozpoczęły się dwa koncerty grającego szlagiery zespołu Ever Green Sekstet ${ }^{28}$. Następnego dnia, w tych samych godzinach występ został powtórzony ${ }^{29}$.

O godz. 14.00 w dniu 15 kwietnia na lotnisku w Nałęczu koło Gębarzewa odbyły się, pod patronatem Wydziału Oświaty, szkolne zawody modeli latających $^{30}$. Na ten sam dzień przewidziano we wszystkich miastach powiatowych województwa poznańskiego zrzut ulotek z samolotów. Wyznaczono 6 aeroklubów, które odpowiedzialne były za akcje zrzutów nad poszczególnymi miastami. W Gnieźnie zadanie to wykonać miały samoloty Aeroklubu Kujawskiego z Inowrocławia ${ }^{31}$.

Żołnierze przygotowujący się do defilady, mającej odbyć się w dniu następnym, stacjonowali na zgrupowaniu w Powidzu. 15 kwietnia Centralny Zespół Artystyczny Wojska Polskiego przygotował dla nich specjalny występ ${ }^{32}$.

Najważniejszą imprezą w Gnieźnie w tym dniu był capstrzyk z udziałem młodzieży szkół średnich i zawodowych pod opieką wychowawców. Odpowiedzialnym za jego organizację z ramienia Wydziału Oświaty i Kultury był podinspektor Władysław Sobczak, z ramienia KP PZPR zaś Tadeusz Stachowiak (dyrektor Zakładów Mięsnych). Rozpoczął się on o godz. 18.30 zbiórką na placu Zasadniczej Szkoły Zawodowej przy ul. Słowackiego. Wymarsz w kierunku amfiteatru w Parku Piastowskim nastąpił o godz. 19.00. Kolumna młodzieży i wojska przeszła ulicami Roosevelta, Przy Rzeźni, Sobieskiego, Chrobrego, Pl. Bohaterów Stalingradu, Tumską, Łaskiego i Poznańską. W godzinach od 19.00 do 20.00 zamknięto z tego powodu ruch kołowy. W przemarszu wzięło udział ok. 3000 młodzieży szkół średnich oraz ok. 200 żołnierzy, 1000 członków ZMS i ok. 2000 harcerzy. Uczestniczyły w nim również zespoły rozrywkowe klubów i świetlic oraz zespółSzkoły Muzycznej. Członkowie ZMS i ZHP ubrani byli w stroje organizacyjne. W czasie pochodu maszerującym przygrywały dwie orkiestry dęte z Gniezna i jedna z Poznania. Żołnierze nieśli palące się pochodnie, a całość imprezy miała charakter barwnego korowodu. Za przygotowanie występów w amfiteatrze i za całość opra-

do 17 IV 1966 r. w związku z organizacją obchodów ostatniego roku 1000-lecia Polski; tamże, sygn. 1881, s. 148. Informacja o przygotowaniach i przebiegu uroczystości Tysiąclecia Państwa Polskiego na terenie powiatu i miasta Gniezna z dn. 16 kwietnia 1966 r.

28 APP, KW PZPR w Poznaniu, sygn. 1314, s. 103.

${ }^{29}$ Tamże, s. 103.

30 Tamże, s. 217.

31 Tamże, s. 48. Plan zrzutów ulotek przez Aerokluby w miastach powiatowych województwa poznańskiego.

${ }^{32}$ APP, KW PZPR w Poznaniu, sygn. 1313, s. 35. Meldunek nr 6 z dn. 15 kwietnia 1966 r. godz. 22. Przebieg uroczystych sesji powiatowych rad narodowych w województwie poznańskim. 
wy muzycznej odpowiedzialny był kierownik Wydziału Kultury Prezydium MRN w Gnieźnie Zygmunt Drejza. Główną atrakcją był występ Centralnego Zespołu Wojska Polskiego. Nad bezpieczeństwem uczestników trwającej do ok. godz. 22.00 imprezy czuwały MO i ORMO. Także 15 kwietnia odbył się apel poległych, przeprowadzony przez dowódcę garnizonu w Gnieźnie na cmentarzu komunalnym przy ul. Witkowskiej. W czasie jego trwania do iluminacji świetnych użyto reflektorów wojskowych. Pierwotnie planowano również złożenie tam urn z ziemią pobraną z miejsc walk z naporem germańskim (to wydarzenie przeniesiono na 16 kwietnia) ${ }^{33}$.

W sobotę 16 kwietnia przewidziana była kulminacja obchodów państwowych. Program na ten dzień opracowany był w najdrobniejszych szczegółach, łącznie z treścią okrzyków wznoszoną przez grupę klakierów, zwaną grupą wiodącą oraz momentami oklasków. Po raz pierwszy oklaski zgromadzonych przewidziano $w$ chwili zapowiedzenia przez spikera zbliżania się gości do trybuny honorowej. Po zajęciu przez nich miejsca na trybunie, wyznaczone osoby wznosiły okrzyki: „Niech żyje Polska Rzeczpospolita Ludowa!”, na co tłum odpowiedzieć miał trzykrotnie: „Niech żyje!” Dalej skandować miano hasło: „Niech żyje Ludowe Wojsko Polskie!”, a na to trzykrotny odzew: „Niech żyje!” Po tym nastąpić miały brawa. Podczas powitania Marszałka Polski Mariana Spychalskiego i I sekretarza KW PZPR Jana Szydlaka przewidziano „burzę oklasków”, a przy dalszych przedstawicielach władz - „zwykłe oklaski". W momencie wejścia M. Spychalskiego na mównicę w celu wygłoszenia przemówienia, na wznoszony przez grupę wiodącą okrzyk: „Niech żyje Marszałek Polski Marian Spychalski!" odpowiedzieć miał aplauz tłumu. W odpowiednich miejscach przemówienia marszałka planowano skandować: „Niech żyje!” i klaskać. Na koniec przemówienia ministra obrony narodowej po okrzykach: „Niech żyje i rozkwita Polska Rzeczpospolita Ludowa!”, "Niech żyje wolność, pokój i socjalizm!” - tłum miał trzykrotnie skandować: „Niech żyje!” Również po odczytaniu aktu fundacyjnego pomnika Mieszka I i Bolesława Chrobrego na wzniesiony okrzyk: „Niech żyje Gniezno - I stolica Polski!” - odzewem miało być trzykrotne: „Niech żyje!”34

Przez cały dzień 16 kwietnia centrum miasta objęte było radiofonizacją. Na Placu Bohaterów Stalingradu, w miejscu wiecu, rozmieszczono łącznie 8 mikrofonów ( 2 na trybunie, 2 na podium dla chóru, 4 w innych punktach) oraz 3 głośniki. Wzdłuż ul. Chrobrego ulokowano głośniki w odległości $200 \mathrm{~m}$ jeden od drugiego. Ponadto przy trybunie defiladowej umieszczo-

33 APP, KW PZPR w Poznaniu, sygn. 1314, s. 164, 191, 201, 207-208; zob. także KW PZPR w Poznaniu, sygn. 1312, s. 163. Dowództwo Lotnictwa Operacyjnego Zarząd Polityczny: Plan zamierzeń w związku z obchodami XXI rocznicy zwycięstwa oraz ostatniego roku obchodów Tysiąclecia Państwa Polskiego w województwie poznańskim (poufne).

${ }^{34}$ APP, KW PZPR w Poznaniu, sygn. 1314, s. 270. Harmonogram grupy wiodącej na dzień 16 kwietnia $1966 \mathrm{r}$. 
no mikrofon, którego użyto $\mathrm{w}$ momencie składania raportu rozpoczynającego defiladę. Na pobliskich ulicach rozmieszczono dalsze głośniki - na ul. Warszawskiej 4, na ul. Dąbrówki 3, na Pl. 21 Stycznia 235. Zorganizowany punkt programowo-informacyjny poprzez zainstalowane $\mathrm{w}$ różnych punktach miasta megafony nadawał specjalnie przygotowany na ten dzień program. Od godz. 8.00 rano do godz. 15.00 emitowano muzykę ludową i pieśni rewolucyjne. O pełnych godzinach, w charakterze przerywników, informowano o programie obchodów Tysiąclecia, historii powstania państwowości polskiej, mającym się odbyć wiecu i o miejscach zbiórek pracowników. Od godz. 15.00 znów podawano informacje o powstaniu państwa polskiego, o historii Gniezna, osiągnięciach największych gnieźnieńskich zakładów pracy (Cukrowni, PKP, Zakładu Wytwórczego Maszyn i Urządzeń Przemysłu Spożywczego, Zakładów Mięsnych, Zakładów Przemysłu Odzieżowego), historii ruchu robotniczego w Gnieźnie, historii i współczesnym szkolnictwie w Gnieźnie, osiągnięciach kulturalnych miasta, przodujących i zasłużonych gnieźnianach, miejscowych przodownikach pracy, ofiarach zaboru i hitleryzmu na ziemi gnieźnieńskiej, oswobodzeniu Gniezna przez armię radziecką, historii chłopstwa i współczesnym rolnictwie powiatu gnieźnieńskiego, rozbudowującym się mieście i czynach społecznych dla jego upiększenia, wreszcie o przybywających na wiec grupach. Przed rozpoczęciem wiecu zaapelowano o serdeczne powitanie władz państwowych i partyjnych oraz przekazywano pozdrowienia mieszkańców Gniezna dla Poznania, Warszawy, Chełma, ziem śląskiej, szczecińskiej, zielonogórskiej i mazurskiej ${ }^{36}$.

Ze względu na przewidywaną znaczną liczbę uczestników manifestacji pracownikom zakładów pracy i instytucji wyznaczono łącznie 10 miejsc zbiór : w hali sportowej jednostki wojskowej przy ul. Cymsa, na ul. M. Konopnickiej, Zielonym Rynku, Przy Rzeźni, skrzyżowaniu Pocztowej i Chrobrego (w okolicach gazowni), u zbiegu ulic Krzywego Koła i Kilińskiego, na ul. Słomianka, Składowej (obok wagonowni PKP), na ul. Mieszka I (przy Liceum Ogólnokształcącym) i na ul. Roosevelta (koło Domu Harcerza). Wyznaczono trasy, którymi po zakończeniu zbiórki grupy uczestników miały kierować się na Pl. Bohaterów Stalingradu. Przewidziano udział 81 gnieźnieńskich zakładów pracy. Dla każdego z nich wyznaczono limit osób, które zakład miał „dostarczyć" na wiec. W zależności od wielkości przedsiębiorstwa władze partyjne żądały różnej ilości manifestantów - od 10 osób pochodzących z takich zakładów, jak Spółdzielnia Pracy Kominiarzy, Przedsiębiorstwo Transportu Samochodowego Łączności, Rejonowe Zakłady Zbożowe, Prokuratura Powiatowa, Biuro Zbytu Drewna, do 1500 w przypadku PKP. Łącznie z młodzieżą szkół średnich, pracownikami PGR-ów, rolnikami z pobliskich wsi oraz oso-

\footnotetext{
35 Tamże, s. 262.

${ }^{36}$ Tamże, s. 261.
} 
bami niezorganizowanymi, udział w wiecu wziąć miało 25725 osób. Zbiórki reprezentantów z poszczególnych zakładów pracy i instytucji odbywać się miały w określonych godzinach. Za zebranie pracowników, odpowiedni porządek i dyscyplinę $w$ punktach zbornych, podczas przemarszu i wiecu odpowiedzialni byli dyrektorzy i kierownicy przedsiębiorstw oraz wyznaczeni członkowie komitetu organizacyjnego. W miejscach zbiórek, na trasach przemarszu i na rynku wstrzymano ruch kołowy oraz rozstawiono służby porządkowe MO i ORMO. Miejsca, które tego wymagały olinowano zabezpieczając tym samym odpowiednią dyscyplinę. Rozstawienie przybywających kolumn na miejscu manifestacji odbyło się według opracowanego planu sytuacyjnego ${ }^{37}$.

Wytypowaniem pięćstetosobowej grupy nauczycieli uczestniczącej w wiecu zajął się Zarząd Oddziału Powiatowego ZNP. Pedagogom towarzyszyła wybrana młodzież szkolna ubrana w stroje galowe ${ }^{38}$.

Już o godz. 10.00 przed południem przybyły do Gniezna pododdziały wojskowe, którym w wieczornej defiladzie towarzyszyć mieli fanfarzyści i orkiestra wojskowa. Dla spikera przygotowano komentarz jaki miał wygłosić podczas parady jednostek wojskowych ${ }^{39}$.

Pierwsze sztafety przybywające na wiec z meldunkami o wykonanych czynach społecznych reprezentowały gromady z powiatu gnieźnieńskiego. Około 680 osób z gromad: Skiereszewo, Jankowo Dolne, Łubowo, Żydowo, Niechanowo, Witkowo i Czerniejewo, pojawiło się w Gnieźnie między godz. 11.30 a 13.30. Nieco później przybyła druga ok. pięćstetosobowa grupa delegatów z gromad: Kiszkowo, Kłecko, Lednogóra, Mieleszyn, Powidz, Sławno i Sokołowo. Obydwie grupy sztafet zbierały się na ul. Wrzesińskiej. Przedstawiciele innych powiatów Wielkopolski zbierali się w czterech punktach zbornych (w Jarocinie, Koninie, Wągrowcu i Poznaniu) i stamtąd kierowali się do Gniezna. Członków wszystkich ekip przejmowali w określonych miejscach wyznaczeni przewodnicy. Kierowane przez nich kolumny motocyklistów udawały się na Pl. Bohaterów Stalingradu, gdzie na ręce Wojewódzkiego Komendanta Zlotu - Stanisława Walendowskiego, składały meldunki o przyjętych do realizacji zobowiązaniach w ramach czynów Tysiąclecia (w rzeczywistości gnieźnieńskie władze administracyjne meldunki zebrały już w dniu poprzednim w gmachu Prezydium PRN, by móc podczas wiecu przedstawić dane zbiorcze). Po złożeniu meldunków przybyłych uczestników sztafet kie-

37 Tamże, s. 263-266. Plan miejsc zbiórek pracowników zakładów pracy i instytucji w dn. 16 kwietnia $1966 \mathrm{r}$.

38 Tamże, s. 201-202.

39 Tamże, s. 165; zob. także KW PZPR w Poznaniu, sygn. 1312, s. 163. Dowództwo Lotnictwa Operacyjnego Zarząd Polityczny: Plan zamierzeń w związku z obchodami XXI rocznicy zwycięstwa oraz ostatniego roku obchodów Tysiąclecia Państwa Polskiego w województwie poznańskim (poufne). 
rowano na stadion przy ul. Wrzesińskiej, gdzie zorganizowano parking dla przybyłych na ok. 900 motocykli i przygotowano posiłek. Stąd udali się pieszo do wojskowej hali sportowej przy ul. Cymsa. Tam wręczono im pamiątkowe proporczyki, po czym uczestniczyli w posiedzeniu FJN. Po przemówieniach przewodniczących PK FJN i PRN przyjęto meldunek, odśpiewano Międzynarodówkę i w kolumnie marszowej skierowano się na Pl. Bohaterów Stalingradu. Po zakończeniu wiecu uczestnicy powrócili na ul. Wrzesińską, skąd w zorganizowanym szyku i wyznaczonymi trasami opuścili Gniezno ${ }^{40}$.

Oprócz sztafet na wiec do Gniezna przybyli zwożeni bezpłatnie delegaci rolników i pracowników gromadzkich rad narodowych z terenu powiatu, wybrani podczas zebrań 13 kwietnia. Wyznaczono osoby odpowiedzialne za przewóz, ustalono potrzebną ilość środków transportu, dokładny plan zwózki delegacji z wyznaczeniem pojazdów, czasu zbiórek, tras przejazdu i czasu dojazdu do koszar przy ul. Wrzesińskiej. Cały tabor zamierzano zaparkować na placu Cukrowni. Po złożeniu meldunków przez sztafety czynów Tysiąclecia zorganizowano koncert orkiestry i występy artystyczne, które trwać miały do godz. 15.45. Następnie sformowano uczestników w kolumnę marszową, która udała się na Pl. Bohaterów Stalingradu, gdzie oczekiwana była o godz. 16.40. Po zakończeniu wiecu delegacje obejrzały defiladę wojskową, po czym całą grupę odprowadzono z orkiestrą na stadion przy ul. Wrzesińskiej. Ze względu na dużą ilość osób, jakie gościły na stadionie, organizatorzy zmuszeni byli do zabezpieczenia sanitarnego w szalety, wodę pitną, wodę do mycia, mydło, ręczniki oraz w artykuły spożywcze, ciepłą kiełbasę, herbatę i oranżadę ${ }^{41}$.

Na kilka minut przed godz. 17.00 nad głowami zebranych na Placu ludzi przeleciał samolot z hasłem: "Czynem uczcimy Tysiąclecie Państwa Polskiego!" Był to pilotowany przez instruktora Józefa Młocka samolot PZL 101 z Centrum Szkolenia w Lesznie. Oprócz niego pojawiły się 3 samoloty z flagami. Szyk maszyn CSS-13 prowadził instruktor Jerzy Jewdokimow, a pozostałe pilotowali instruktor Telesfor Szulc i pilot Bogdan Jankowski. Po nich przeleciał sterowany przez instruktora Andrzeja Wasiutyńskiego samolot PZL 101 z aeroklubu poznańskiego, prowadzący na wieloholu 3 szybowce Mucha Standard, za sterami których zasiadali piloci - Gromosław Czempiński, Andrzej Rataj i Zdzisław Płotkowiak. Start samolotów nastąpił z lotniska Ligowiec o godz. 16.10, w odstępach jednominutowych. Odlot ko-

40 APP, KW PZPR w Poznaniu, sygn. 1312, s.202-209. Projekt programu obchodów rocznicy forsowania przez II Armię WP Nysy Łużyckiej; tamże, sygn. 1313, s. 39. Zestawienie ilości uczestników imprez politycznych na terenie województwa i miasta Poznania w dn. 13-17 kwietnia 1966 r.; tamże, sygn. 1314, s. 75-79; tamże, sygn. 1314, s. 128a, 271-272, 275; tamże, sygn. 1881, s. 149. Informacja o przygotowaniach i przebiegu uroczystości Tysiąclecia Państwa Polskiego na terenie powiatu i miasta Gniezna.

41 APP, KW PZPR w Poznaniu, sygn. 1314, s. 209-214. 
lumny miał miejsce o godz. 16.20. Nad Gniezno samoloty przyleciały z kierunku południowego na wysokości $200 \mathrm{~m}$ o godz. 16.55. Przelot formacji trwał 3 minuty. Powrót na lotnisko w Ligowcu przewidziano na godz. $17.25^{42}$.

Wiec, będący centralną częścią obchodów, rozpoczął się o godz. 17.00 wejściem przedstawicieli władz centralnych i wojewódzkich na trybunę honorową. Miejsce na niej zaproszeni goście zajmowali według wcześniej ustalonej kolejności. W pierwszym rzędzie znalazło się 20 osób, z tego 5 z Gniezna, resztę stanowili przywódcy partyjni szczebla centralnego i wojewódzkiego na czele z członkiem Komitetu Politycznego PZPR marsz. Marianem Spychalskim oraz generalicja. Wśród wyróżnionych gnieźnian znaleźli się: Stanisław Kulesza (I sekretarz KP PZPR), Stanisław Staszak (przewodniczący PRN), Tadeusz Sobieralski (przewodniczący MRN), Bolesława Maciejewska (posłanka) i Zofia Kaźmierczak (rolniczka). Do drugiego rzędu zaproszono 21 osób, z czego 5 z Gniezna. W trzecim rzędzie znalazło się 22 zaproszonych gości, w większości z powiatu gnieźnieńskiego ${ }^{43}$. Po zajęciu przez gości miejsc na trybunie odegrano hymn państwowy i oddano 12 salw armatnich. Następnie wypuszczono 5 balonów z flagami. Przybyłych powitał T. Sobieralski. Kolejnym mówcą był przedstawiciel władz centralnych marsz. M. Spychalski, który na wstępie pozdrowił wszystkich zebranych. W dalszej części swego przemówienia podkreślił chlubne tradycje i dorobek mieszkańców Wielkopolski, napiętnował orędzie biskupów polskich do biskupów niemieckich, potępił rewanżystowskie dążenia rządu zachodnioniemieckiego oraz podziękował $w$ imieniu naczelnych władz partyjnych i państwowych mieszkańcom województwa za patriotyczną postawę w "Czynach Tysiąclecia" ${ }^{44}$.

Po przemówieniu M. Spychalskiego Komendant Wojewódzkiego Zlotu Sztafetowego poseł S. Walendowski złożył marszałkowi odebrany od sztafet motocyklowych meldunek o "Czynie Tysiąclecia” mieszkańców miast i wsi ziemi wielkopolskiej. Łączna wartość podjętych przedsięwzięć wynosiła $1300000000 z^{45}$. Podczas składania meldunku, w przygotowanym specjalnie na tę okazję apelu dano jak zwykle upust antyniemieckiej fobii. Nie zabrakło krytycznych odniesień w stosunku do orędzia biskupów polskich. W dalszej kolejności poznański radny Marian Paluchowski odczytał akt fundacyjny budowy pomnika Mieszka I i Bolesława Chrobrego. Monument początkowo planowano ustawić przed katedrą, w miejscu zburzonego przez Niemców pomnika Bolesława Chrobrego. W jego cokół zamierzano wmuro-

42 APP, KW PZPR w Poznaniu, sygn. 1314, s. 46-47, 156; „Głos Wielkopolski”, wyd. AB, nr 90(6897), z 17/18 kwietnia 1966 r., s. 2.

43 APP, KW PZPR w Poznaniu, sygn. 1314, s. 271-275, 277-279.

44 Tekst przemówienia podała w całości prasa: „Głos Wielkopolski”, nr 90(6897) z 17/18 kwietnia 1966 r., s. 3; „Gazeta Poznańska”, nr 90 z 18 kwietnia 1966r., s. 4-5.

45 „Przemiany. Miesięcznik Regionalny Ziemi Gnieźnieńskiej”, nr 5(16), maj 1966, s. 2-3. 
wać urny z ziemią pobraną z 11 pól bitewnych, na których w ciągu tysiąclecia toczono walki z „germańskim najeźdźcą". Szczególnie uroczyście pobrano ziemię z pola bitwy na Psim Polu. Tamtejsze władze dołączyły do urny artystycznie wykonany akt erekcyjny, który miał być również wmurowany pod gnieźnieński pomnik pierwszych władców Polski. Urny z ziemią składały przy dźwiękach fanfar i werbli delegacje FJN, LWP, ZBoWiD oraz organizacji młodzieżowych, przebrane w historyczne stroje - wojów Mieszka I spod Cedyni, Bolesława Krzywoustego spod Psiego Pola, rycerzy Jagiełły spod Grunwaldu, ludu wielkopolskiego spod Książa i Miłosławia, powstańców wielkopolskich spod Ujścia i Kargowej, harcerzy z Kłecka i piechurów Armii Poznań spod Łęczycy, czołgistów spod Studzianek, żołnierzy polskich z Wału Pomorskiego, spod Kołobrzegu i Siekierek ${ }^{46}$. W czasie składania urn lektor wygłaszał przez głośniki komentarz historyczny ${ }^{47}$.

Na koniec wiecu odśpiewano Międzynarodówkę i wypuszczono 1500 gołębi pocztowych ${ }^{48}$. Liczbę wszystkich uczestników gnieźnieńskiego wiecu w dniu 16 kwietnia organizatorzy szacowali na ok. 40000 osób ${ }^{49}$. W trakcie wiecu przejście od Pl. Bohaterów Stalingradu do katedry ul. Tumską było zablokowane szpalerem milicji i wojska. Jego celem było zatrzymanie osób biorących udział w manifestacji na rynku i niedopuszczenie ich do udziału w obchodach kościelnych. W tym samym czasie odbywał się wyjazd obrazu Matki Boskiej Częstochowskiej z Gniezna do Poznania ${ }^{50}$. Mimo blokady, wiele osób znajdujących się wcześniej na rynku, dotarło na czas w pobliże katedry ${ }^{51}$.

Około godz. 19.00 rozpoczęła się druga część uroczystości - defilada wojskowa. Przygotowania do niej trwały kilka dni. Prowadzone próby odbywały się przy udziale licznie zgromadzonych mieszkańców Gniezna. Wśród części starszego rocznika żołnierzy, który miał być zwolniony do rezerwy w dniu 24 kwietnia, a oddelegowany został do przygotowywanej para-

46 APP, KW PZPR w Poznaniu, sygn. 1313, s. 34. Meldunek nr 6 z dn. 15 kwietnia 1966 r., godz. 22. Przebieg uroczystych sesji powiatowych rad narodowych w województwie poznańskim; tamże, sygn. 1314, s. 131-132; "Głos Wielkopolski”, wyd. AB, nr 90 (6897), 17/18 kwietnia 1966r., s. 2; „Gazeta Poznańska”, nr 90 z 18 kwietnia 1966 r., s. 5. Do momentu pisania artykułu w 2017 r. urny znajdowały się nadal w magazynie Muzeum Początków Państwa Polskiego.

47 APP, KW PZPR w Poznaniu, sygn. 1314, s. 257; Narodowe Archiwum Cyfrowe, Nagranie Polskiego Radia, Transmisja z przebiegu manifestacji ludności Gniezna z okazji jubileuszu Tysiąclecia Państwa Polskiego oraz 21. rocznicy sforsowania Odry i Nysy przez Wojsko Polskie, https:/ / audiovis.nac.gov.pl/obraz/69307/, (dostęp 15 lutego 2016).

48 APP, KW PZPR w Poznaniu, sygn. 1314, s. 257.

49 APP, KW PZPR w Poznaniu, sygn. 1313, s. 39. Podobną liczbę podaje także pochodząca z maja 1966 r. Informacja o przygotowaniach i przebiegu ostatniego roku obchodów Tysiąclecia Państwa Polskiego w mieście Poznaniu i województwie poznańskim, tamże, s. 51.

${ }^{50}$ APP, KW PZPR w Poznaniu, sygn. 1314, s. 91.

51 T. Krawczak, Partyjno-państwowa koncepcja obchodów Tysiaclecia Państwa Polskiego, [w:] Milenium kontra Tysiąclecie 1966, red. K. Białecki, S. Jankowiak, J. Miłosz, Poznań 2007, s. 78. 
dy, pojawiły się obawy, czy nie zostanie im wydłużona służba wojskowa ${ }^{52}$. Do przyjęcia defilady wojskowej ustawiono drugą trybunę na ul. Chrobrego 12b przy budynku PKO. Goście przeszli tam ok. godz. 18.40. Po zajęciu przez nich miejsc grupa 60 harcerek wręczyła kwiaty wszystkim znajdującym się na niej osobom. Odegraniem hymnu i hejnału o godz. 19.00 otwarto paradę. Uczestniczyły w niej pododdziały piesze, pływające pojazdy bojowe różnych typów oraz rakiety „ziemia-powietrze” i „ziemia-ziemia”. Defilada zakończyła się o zmierzchu ${ }^{53}$.

Tak duża impreza, jaka odbyć się miała 16 kwietnia wymagała wszechstronnego i drobiazgowego przygotowania. Wśród planów obchodów rocznicy powstania państwa polskiego nie zabrakło scenariusza dekoracji miasta. Z uwagi na miejsce uroczystości szczególny akcent położono na przygotowanie centralnych placów i ulic. Wśród nich znalazły się Pl. Bohaterów Stalingradu (miejsce wiecu), Pl. 21 Stycznia (zgrupowanie wojska przed defiladą), ul. Poznańska (z pominięciem szerokości katedry) oraz ulice Tumska, Chrobrego, Lecha, Dąbrówki, Warszawska, Wrzesińska i Armii Czerwonej. Hasła na transparentach odnosić się miały do dorobku władzy ludowej, wydarzeń z historii Polski uznanych przez ówczesne władze za postępowe, ruchu robotniczego, walki $\mathrm{z}$ rewizjonizmem zachodnioniemieckim i powrotem ziem zachodnich do macierzy. Zbudowana na Pl. Bohaterów Stalingradu przy jego północnej pierzei trybuna honorowa miała wysokość $2 \mathrm{~m}$, długość $15 \mathrm{~m}$ i szerokość - $4 \mathrm{~m}$. Pomieścić mogła 100 osób. Balustrada trybuny udekorowana była biało-czerwonym sztandarem. Wzdłuż przedniej ściany trybuny ustawiono przybranie z zieleni, a po jej obydwu stronach 6 koszy z białoczerwonymi i czerwonymi szturmówkami. Na fasadzie budynku za trybuną umieszczono wizerunek piastowskiego orła, a pod nim napis: „1000 lat Państwa Polskiego". Pod godłem umieszczono czerwoną wstęgę, a na 6 balkonach zamontowano szturmówki biało-czerwone i czerwone. Wszystkie fasady budynków przy Pl. Bohaterów Stalingradu ozdobiono flagami. Po przeciwnej stronie trybuny, na południowej pierzei rynku, umieszczono 15 portretów wybitnych Polaków z całej tysiącletniej historii państwa. Wśród nich znaleźli się m.in.: Ludwik Waryński, Julian Marchlewski, Marcin Kasprzak, Marceli Nowotko, Romuald Traugutt, Tadeusz Kościuszko, Piotr Ściegienny, Stanisław Staszic, Mikołaj Kopernik, Maria Skłodowska-Curie, Fryderyk Chopin. Rosnące przy placu drzewa, pozbawione jeszcze liści, udekorowano czerwonymi magnoliami z krepy. Słupy oświetleniowe przystrojono szturmówkami i balonami. Na miejscu rozebranej posesji przy Pl. Bohaterów

52 APP, KW PZPR w Poznaniu, sygn. 1313, s. 35.

53 APP, KW PZPR w Poznaniu, sygn. 1881, s. 150. Informacja o przygotowaniach i przebiegu uroczystości Tysiąclecia Państwa Polskiego na terenie powiatu i miasta Gniezna, z dn. 16 kwietnia $1966 \mathrm{r}$. 
Stalingradu i u wylotu zamkniętej ul. Kaszarskiej umieszczono stoiska z planszami na temat historii ziemi gnieźnieńskiej i Grodu Lecha. Plac 21 Stycznia przyozdobiono biało-czerwonymi i czerwonymi flagami oraz czerwoną wstęgą z wypisanym hasłem. Ulica Chrobrego, na której odbywała się defilada wojskowa, oprócz flag i szturmówek udekorowana została 6 transparentami, przy wylotach ul. Rzeźnickiej, Mieszka I, Marchlewskiego, przy poczcie, przy ul. Mickiewicza i przy MPGKiM. W wystawach sklepowych znajdowały się ekspozycje dotyczące Tysiąclecia Państwa Polskiego oraz portrety dostojników partyjnych i państwowych. Na elewacji Prezydium MRN umieszczono portret marsz. M. Spychalskiego oraz chorągwie. Dokładnie zaplanowano miejsce rozmieszczenia i liczbę flag, transparentów z hasłami na budynkach państwowych, koszy z kwiatami i szturmówkami. Przy ul. Lecha przystrojono znajdujące się tam obiekty państwowe - Szpital Dziecięcy, budynek administracji PKP i Prezydium PRN. Na pozostałych ulicach przewidziano umieszczenie flag na wkopanych $\mathrm{w}$ tym celu słupach. Budynki instytucji i zakładów pracy były ozdabiane według projektów wykonanych przez plastyków. Za udekorowanie domów mieszkalnych odpowiadały Miejski Zarząd Budynków Mieszkalnych, Zrzeszenie Prywatnych Właścicieli Nieruchomości i komitety blokowe ${ }^{54}$.

Ważnym zadaniem było odpowiednie zaopatrzenie miasta w napoje i artykuły spożywcze. Wprowadzono zakaz sprzedaży i podawania napojów alkoholowych powyżej 4,5\% w placówkach handlu detalicznego oraz w zakładach żywienia zbiorowego do godz. 18.00. Wszystkie sklepy, zarówno branży spożywczej, jak i przemysłowej, czynne być miały od godz. 8.00 do 15.00, zaś wyznaczone sklepy dyżurujące do godz. 22.00 (z przerwą w godz. 15-20). W centrum miasta wyznaczono 12 sklepów dyżurujących: 3 branży piekarniczej, 3 branży ogólnospożywczej i 6 ze sprzedażą wędlin. Wszystkiekioski spożywcze należące do MHD, PSS oraz sklepy cukiernicze Spółdzielni Inwalidów „Lechia” czynne były bez przerwy do godz. 22.00. Sprzedawały one głównie piwo i napoje gazowane. Ponadto na stadionie przy ul. Wrzesińskiej (w miejscu parkingu motocykli uczestników sztafet) czynne było stoisko MHD sprzedające wędliny na ciepło i inne artykuły spożywcze ${ }^{55}$.

Równie ważne było zabezpieczenie sanitarne imprezy, za które odpowiedzialnych było 3 lekarzy: Zbigniew Baranowski, Bogdan Mroczkowski i Jerzy Kucharski. Posterunki sanitarne zorganizowano w 21 miejscach. Ponadto przewidziano dyżury karetek sanitarnych wraz z zespołami ${ }^{56}$.

54 APP, KW PZPR w Poznaniu, sygn. 1314, s. 218-227. Scenariusz dekoracji miasta Gniezna w związku z obchodami 1000-lecia Państwa Polskiego.

55 APP, KW PZPR w Poznaniu, sygn. 1314, s. 228.

56 Tamże, s. 229. 
Transmisję z uroczystości przeprowadziło Polskie Radio w programie ogólnopolskim. Obejmowała ona cały przebieg wiecu na Pl. Bohaterów Stalingradu, ale bez defilady wojskowej. Gnieźnieńską imprezę obsługiwał wóz transmisyjny z Warszawy, a sprawozdawcami byli Erazm Fethke z Warszawy i Andrzej Napierała z Poznania ${ }^{57}$.

Ze względu na wzmożony ruch pieszych na ulicach miasta i zlokalizowanie wiecu w miejscu ważnego węzła komunikacyjnego, w godzinach od 15.30 do 20.30 zawieszono kursy miejskiej komunikacji autobusowej. W tym samym dniu od godz. 13.00 wstrzymano wyjazdy z miasta liniami PKP i PKS ${ }^{58}$.

Lansowane przez partyjny aktyw ideologiczne hasła były dla przeciętnego Polaka zupełnie obce, natomiast powszechną akceptację zyskiwały propozycje czynów społecznych, których efekty miały służyć ogółowi. Chcąc wykorzystać dla własnych celów społeczny zapał, władze administracyjne udzielały pomocy finansowej przy realizacji zadeklarowanych czynów. Użyczano sprzętu (zwłaszcza budowlanego), deficytowych materiałów, wysyłano w teren fachowców. Uczestnicy czynów społecznych stanowili niejednokrotnie darmową siłę roboczą. W wewnętrznych wytycznych nakazywano wręcz, by społeczne zobowiązania koncentrowały się na budowie i naprawie dróg, pracach melioracyjnych, przygotowaniu szkół do wdrożenia ośmioletniego planu nauczania, budowie infrastruktury w postaci świetlic wiejskich, wodociągów, studni, zbiorników na wodę. Trudną dziś do zweryfikowania wartość wszystkich czynów społecznych na terenie Gniezna oceniano na prawie $22000000 z^{759}$.

Program gnieźnieńskich świeckich obchodów rozpoczynających podsumowanie jubileuszu Tysiąclecia Państwa Polskiego zaskakuje swoim rozmachem. Budzi on uznanie zwłaszcza, gdy zważy się krótki czas od nakreślenia planu ich przebiegu do realizacji. Tak dużej świeckiej imprezy nie było w Gnieźnie ani wcześniej, ani później. Niektóre jej elementy, wyreżyserowane przez wybitnych fachowców, swoim poziomem wywoływały powszechny podziw. Zarówno przebieg imprezy jak i wysoką frekwencję podczas jej przebiegu, KP PZPR uznał za własny sukces. W oficjalnej propagandzie miał to być dowód poparcia obywateli dla aktualnej linii politycznej władzy ludowej. W sprawozdaniach pomijano wstydliwy fakt, że obecność podczas kul-

57 Tamże, s. 43.

58 APP, KW PZPR w Poznaniu, sygn. 1881, s. 148. Informacja o przygotowaniach i przebiegu uroczystości Tysiąclecia Państwa Polskiego na terenie powiatu i miasta Gniezna, z dn. 16 kwietnia $1966 \mathrm{r}$.

${ }^{59}$ APP, KW PZPR w Poznaniu, sygn. 1881, s. 161-164. Dzięki pracom społecznym lub przy znacznym ich udziale powstały w Gnieźnie m.in. Park Piastowski nad jeziorem Jelonek, Park XX-lecia, odnowiono fasady wielu kamienic, naprawiono nawierzchnie ulic, przystąpiono do modernizacji oczyszczalni ścieków, poprawiono ogólną estetykę miasta - APP OG, PMRN w Gnieźnie, sygn. 494, s. 9-12. 
minacyjnego wiecu w znacznym stopniu nie była dobrowolna ${ }^{60}$. Narzuca się wniosek, że głównym celem obchodów świeckich stało się ograniczenie zasięgu uroczystości kościelnych, środkiem do jego zrealizowania zaś - zapewnienie szerokiego udziału ludności w jubileuszu państwowym. Koszty finansowe osiągnięcia tego celu nie odgrywały większej roli.

Marek Szczepaniak, Grażyna Tyrchan

\title{
Kulminacja ogólnopolskich świeckich obchodów Tysiąclecia Państwa Polskiego w Gnieźnie w kwietniu 1966 r.
}

\begin{abstract}
Streszczenie
W artykule, po raz pierwszy przedstawiono szczegóły dotyczące gnieźnieńskich świeckich obchodów Tysiąclecia Państwa Polskiego od 9 do 16 kwietnia 1966 roku. W zamierzeniach władz komunistycznych miały one stać się inauguracją uroczystości ogólnopolskich oraz kulminacją wieloletnich przygotowań prowadzonych na szczeblu lokalnym, wojewódzkim i ogólnopolskim. Wskutek działań politycznych, uroczystości nabrały charakteru konfrontacyjnego w stosunku do obchodów Millennium Chrztu Polski przygotowanych i realizowanych przez władze kościelne. Autorzy artykułu w swojej pracy oparli się na aktach z zasobu Archiwum Państwowego w Poznaniu i jego Oddziału w Gnieźnie. Uwzględniając sprawozdania organów władz terenowych, zrekonstruowali po raz pierwszy podejmowane $w$ ramach obchodów działania społeczne w poszczególnych wioskach i gromadach ziemi gnieźnieńskiej. Zwrócono uwagę, na niejednokrotnie dalekie od ideologicznych, motywacje podejmowanych przez ludność akcji gospodarczych. Odtwarzając przebieg wydarzeń, przedstawiono cele i motywy jakimi kierowali się pomysłodawcy przy ustalaniu harmonogramu i scenariuszy poszczególnych imprez. Prezentowane $\mathrm{w}$ artykule cyfrowe dane źródłowe pozwoliły na nakreślenie rozmachu jubileuszowej gali.
\end{abstract}

Słowa kluczowe: Tysiąclecie, Millennium, Gniezno, 1966, obchody

\section{The culmination of nationwide secular Celebrations of 1000 years of Polish statehood in Gniezno in April 1996}

\begin{abstract}
The article comprises the first description of the events surrounding secular celebrations of 1000 years of Polish statehood in Gniezno (April 9-April 16, 1966). Poland's communist authorities intended for these events to be the inauguration of national celebrations and the culmination of

${ }^{60}$ APP, KW PZPR w Poznaniu, sygn. 7. Referat na XIII Konferencję sprawozdawczo-wyborczą KP PZPR w Gnieźnie, Gniezno październik 1966 r. (do użytku wewnętrznego). Można przypuszczać, że część mieszkańców prawdopodobnie dobrowolnie wzięła by udział w organizowanych przez władze imprezach, niemożliwe jest jednak stwierdzenie, jaką liczbę uczestników by one zgromadziły.
\end{abstract}


long preparations at the local, regional, and national levels. Due to political factors, the celebrations clashed with the celebration of the $1000^{\text {th }}$ anniversary of Poland's christening, prepared and hosted by the Church authorities. The authors of the article used files from the fonds of the National Archive in Poznań and its branch in Gniezno. Taking into consideration the reports of local authorities, the authors reconstructed (for the first time) the social actions undertaken in villages and towns in the Gniezno region as part of celebrations. It was pointed out that local people were rarely motivated to undertake these actions by ideological considerations. The authors reconstructed the course of events, and therefore were able to demonstrate what the originators' goals and motivations were when developing the schedules and scenarios of particular events. Digital source data presented in the article also allowed them to demonstrate how elaborate the celebrations were.

Keywords: Millennium, Gniezno, 1966, celebrations 